\title{
The development of adequate finite element models of load-bearing structures coating "Vnukovo-1 airport complex" to solve the problems of monitoring their technical condition
}

\author{
Andrey Korgin", Valentin Ermakov, Laith Zeyd Kilani, Danila Koknaev and Artem \\ Golovkin
}

Moscow State University of Civil Engineering, Yaroslavskoe shosse, 26, Moscow, 129337, Russia

\begin{abstract}
This article considers the issues of designing adequate finite element models of weight-bearing structures based on the roof structures of the Vnukovo-1 airport, which is made in the form of a spatial core structure. Additional actions on the covering structure model in terms of the strength checking calculation procedure are presented, its purpose is to make the adequate model for its further use in the design of structural health monitoring. The article presents the results of modeling, comparative research with the data of nature experiments
\end{abstract}

\section{Introduction}

The maintenance of unique buildings and structures of increased responsibility should be accompanied by the procedure of automatic monitoring of the technical state of loadbearing structures [1-3]. This type of monitoring requires: the installation of measuring equipment on load-bearing structures [3-6]; the presence of data networks, the evaluation system (software) of the obtained results.

The difficulty of creating an effective automatic monitoring system lies in real assessment of the obtained values of measuring equipment, since the limit range for unique structures parameters are not set by the regulatory documents. Finding the limit ranges of the measured parameters is implemented by analyzing the stress-strain state of structures caused by the worst case load combination (hazard models) using an adequate computer model.

An adequate model is a calculation model of a building or structures that is based on design documentation and the results of a structural technical report, taking into account defects and damage, and accurately describing accurate behavior of the structure [7-9]. The values of calculated displacements, rotation angles, and strains that matches the data of field experiments can considered as a criterion for the adequacy of the model. Also, the

*Corresponding author: zeydkilani@mgsu.ru 
adequacy assessment can be implemented by comparing the calculated frequencies and vibration modes with the experimental values [10-13].

Significant contribution to the formation of natural frequencies and vibration modes is made by the distribution of the masses (the weight of the structure and equipment and loading distribution) and the rigidity of structural elements (spans, material, cross-section etc.).

\section{Methodology}

Covering structures are dimensional structures supporting on reinforced concrete columns, divided into blocks by expansion joints (Fig. 1, 2.). The column spacing is $25 \mathrm{~m}$, the average size of the block is $110 \times 90 \mathrm{~m}$.

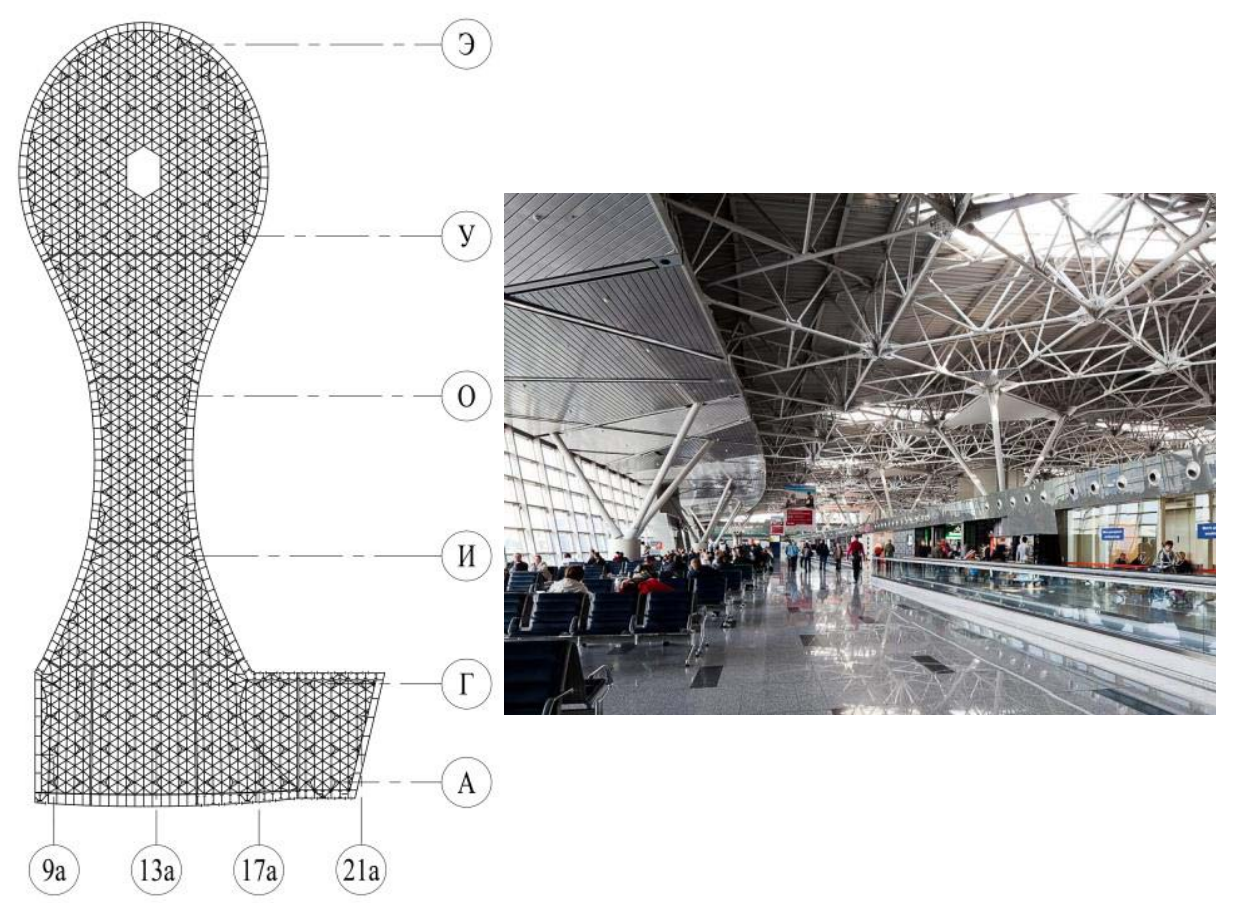

Fig. 1. General scheme of the covering structure

Fig. 2. General view of the covering structure

Each block consists of many structural elements, structure nodes and structural elements (truss chords, braces, purlins) in the form of I-beams and pipes

The standard calculation of the load-bearing capacity of this structure can be implemented using various software based on the finite element method. In this article, the ANSYS software was chosen.

Three-dimensional drawings of the structural blocks of the covering structure for the formation of FEM models were presented in the *.DWG format, and were divided into the main layers - upper and bottom chords, braces, purlins.

The work with the models was implemented according to the following algorithm (Fig. 3): 
1. Seperation the lines in AutoCAD drawing into layers corresponding to each type of cross-section in accordance with the project documentation and research results.

2. Drawing the surfaces for modeling the covering and glazing of floor lanterns.

3. Layer-by-layer export of lines and surfaces in *.IGES format

4.One-by-one import of *.IGES files into the ANSYS software with cross-sections appointing.

5. Meshing lines and surfaces.

6. Fixing (applying displacement) the model, assigning materials, applying a load in the form of free-fall acceleration to take into account for the structure's own weight.

7.Starting the modal analysis to determine the frequencies and waveforms of the structure.

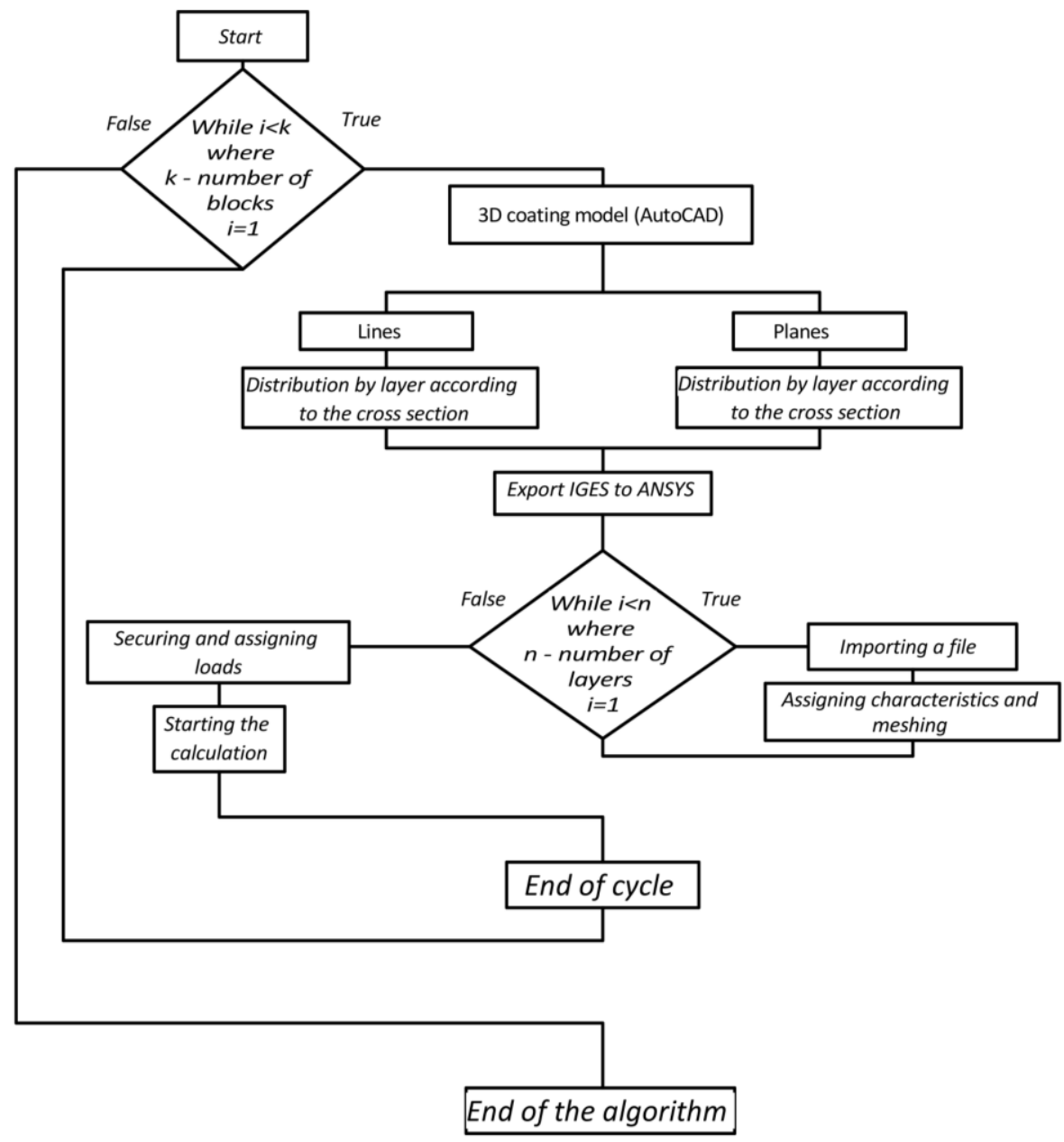

Fig. 3. Flowchart of the algorithm for working with models

At the preliminary work, it turned out that the obtained initial models contain inaccuracies related to the geometric dimensional position of the elements, that causes incorrect calculated values of the natural frequencies, as well as the vibration forms of the structures. These inaccuracies require a corrections of the model in the source file*. DWG, so it is necessary to repeat the algorithm multiple times (Fig. 3). 
To automate the process of debugging models and modeling techniques, the macro were developed in the APDL programming language in the ANSYS for each block, which significantly speed up the process.

The control code of the macro automatically imported the lines and planes, assigned the type of cross-section and meshed them, applied load and displacements, and set the calculation parameters. The original model was edited in the AutoCAD software package, which has the necessary functionality for working with the geometry of dimensional elements.

At the next stage, the calculation model was corrected by changing the rigidity of the full structure (the support conditions) and taking into account the presence of additional masses identified during of visual inspection of the structures.

To obtain correct results, 2 types of finite elements were used: SHELL181 and BEAM188, which are the most appropriate for the types of structural elements of the coating.

The BEAM188 rod element, a linear two-node spatial beam element with six degrees of freedom at each node, is suitable for tasks with large rotations and deformations.

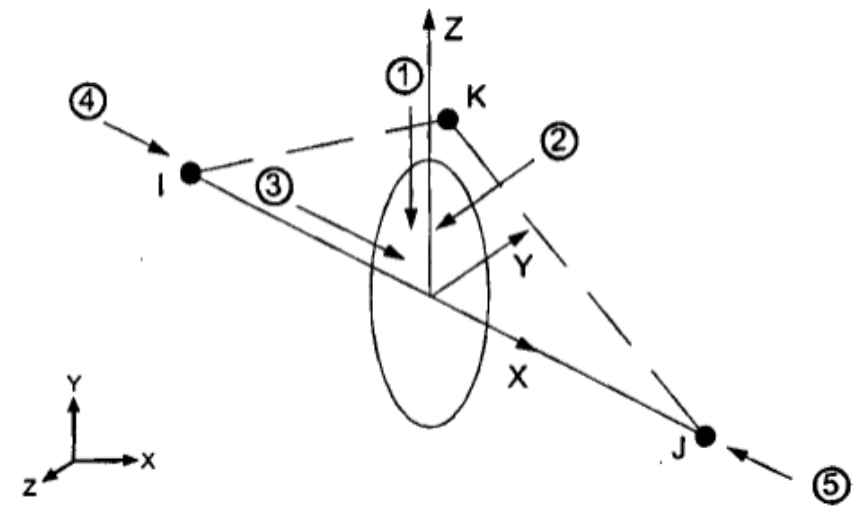

Fig. 4. Element BEAM188

Shell element SHELL181, used for elements of small or mild thickness, has four nodes and six degrees of freedom in each node, the shells can be either single-layer or multi-layer.

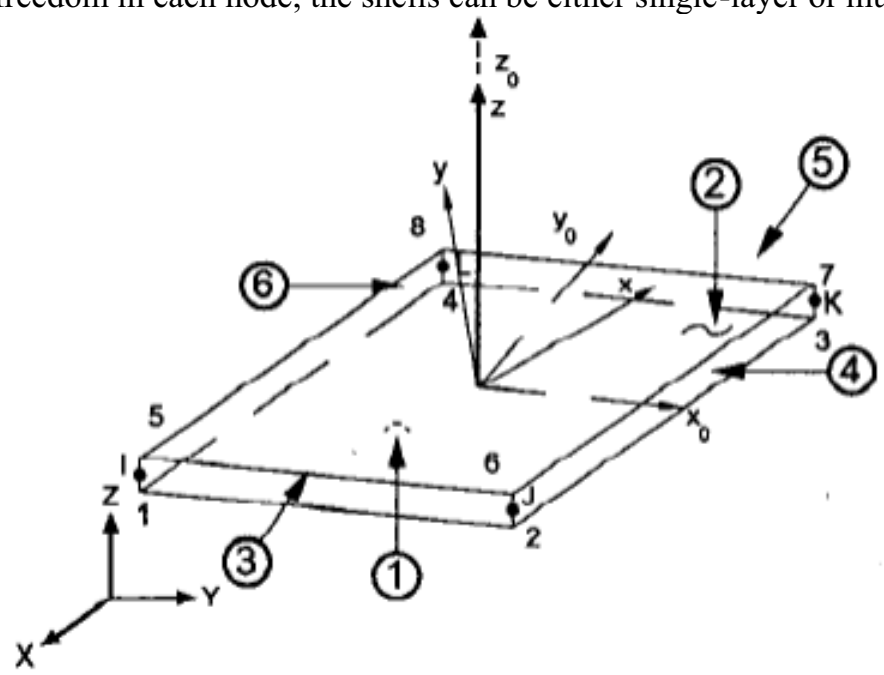

Fig. 5. Element SHELL188 
The roof of the airport is represented by shell elements - multilayer surfaces. The main contribution to the rigidity of the full structure is made by: Corrugated sheet 127/320/0,75, 2 layers of foam glass "FOAMGLAS T4" $100 \mathrm{~mm}$ aluminum roof Kalzip.

As an added masses to the element of the main covering, The load from materials of the roof and technological equipment was modeled as a mass $-4,8 \cdot 10-6 \mathrm{~kg} / \mathrm{cm} 2$. Similarly, for the structures of roof skylight, the load from the structure of the roof glazing frame was modeled as $-1,01 \cdot 10-5 \mathrm{~kg} / \mathrm{cm} 2$, model was loaded with gravitational acceleration of 981 $\mathrm{cm} / \mathrm{s} 2$.

It should be noted that the models were loaded according to loads applied at the time of the field tests, i.e., without considering snow loads.

Full-scale dynamic tests to determine the frequencies and forms of natural vibrations/oscillations were implemented by a seismologists of the Altai-Sayan Branch of the Federal Research Center "Unified Geophysical Service" Russian Academy of Science with the help of autonomous recorders "Baikal-AS-75", "Baikal-AS-88" and geophones A1632/A1638.

\section{Results}

The adequate of the models was evaluated using two central blocks No. 6 and 7. The results of the evaluation of the comparing of the vibration frequencies are presented in Table 1, and the comparison of the vibration forms is shown in Figures 6-8.

Table 1. Comparison of calculated and experimental data for blocks No. 6, 7 .

\begin{tabular}{|c|c|c|c|}
\hline $\begin{array}{c}\text { Frequency sequence } \\
\text { number }\end{array}$ & $\begin{array}{c}\text { Calculated values of } \\
\text { frequencies, Hz }\end{array}$ & $\begin{array}{c}\text { Experimental values of } \\
\text { frequencies, Hz }\end{array}$ & $\begin{array}{c}\text { Variance of results, } \\
\mathbf{\%}\end{array}$ \\
\hline \multicolumn{5}{|c|}{ Block 6 } \\
\hline 1 & 3.1667 & 3.027 & 4.62 \\
\hline 2 & 3.4957 & 3.344 & 4.54 \\
\hline 3 & 3.7938 & 3.711 & 2.23 \\
\hline \multicolumn{5}{|c|}{ Block 7 } \\
\hline 1 & 3.1549 & 3.027 & 2.7 \\
\hline 2 & 3.3202 & 3.344 & 0.7 \\
\hline 3 & 3.4279 & 3.711 & 7.6 \\
\hline
\end{tabular}


a)

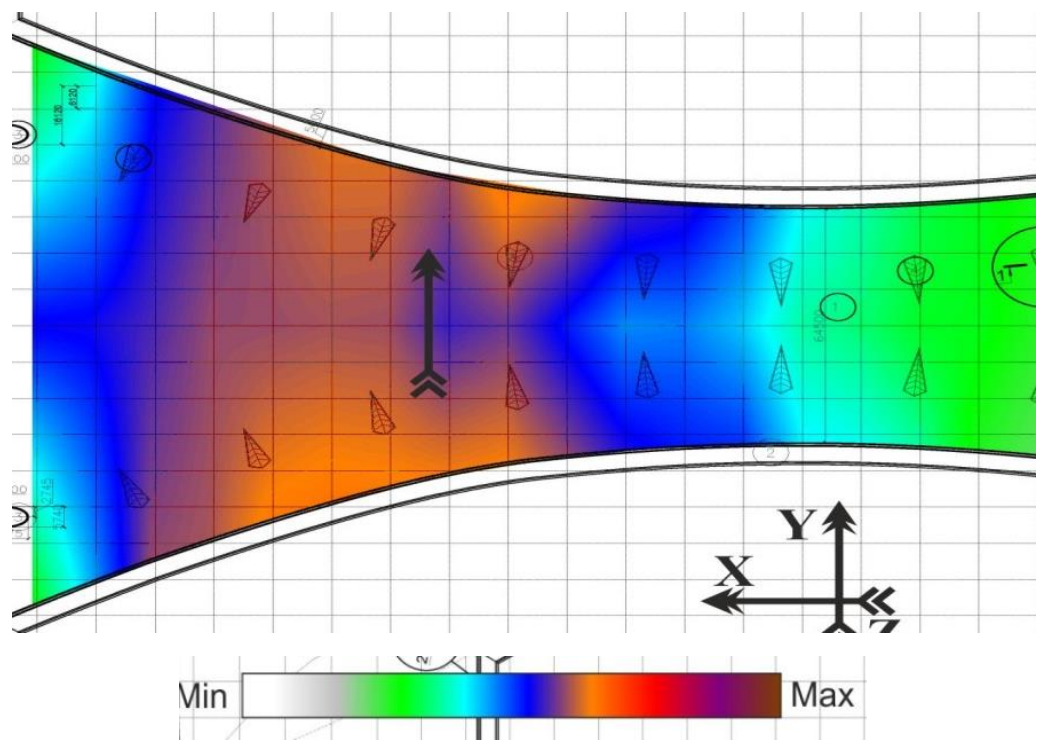

$3,027 \mathrm{~Hz}$

b)

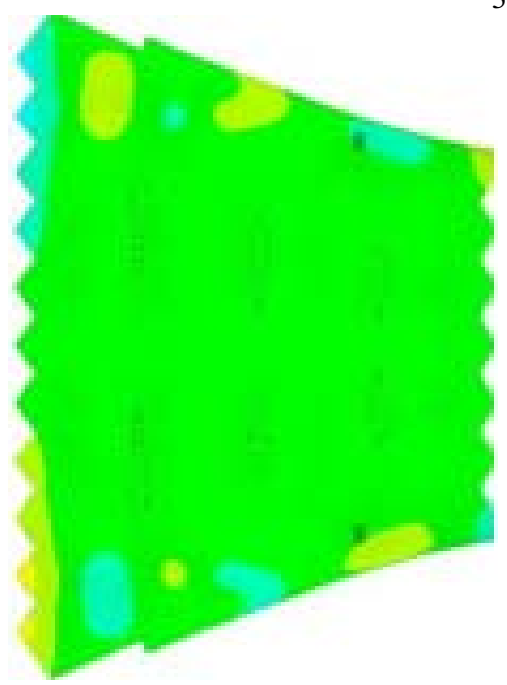

$3.167 \mathrm{~Hz}$

Fig. 6. Comparative analysis of the first transverse waveform: a) the shape (amplitude) and frequency of vibrations of the covering as a result of nature tests; $b$ ) the shape and frequency of vibrations of the block 6 ; c) the shape and frequency of vibrations of the block 7 
a)

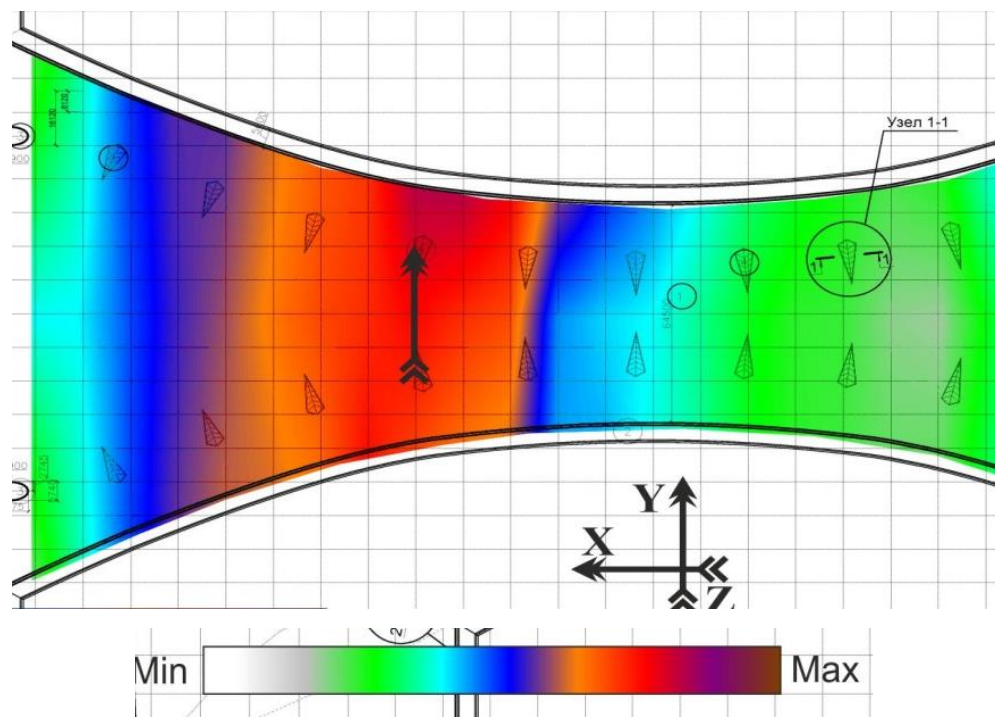

$3.344 \mathrm{~Hz}$

b)

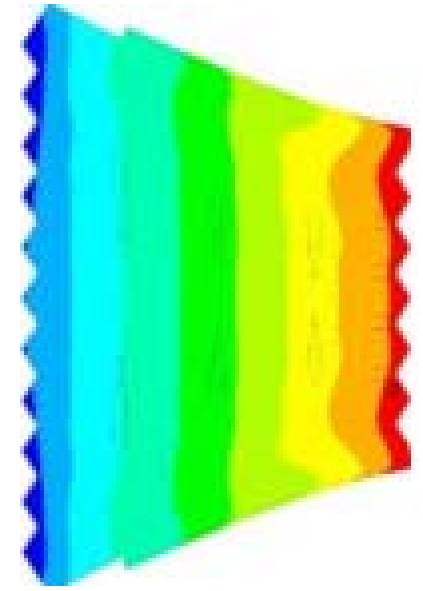

$3.496 \mathrm{~Hz}$ c)



$3.320 \mathrm{~Hz}$

Fig. 7. Comparative analysis of the second transverse waveform: a) the shape (amplitude) and frequency of vibrations of the coating as a result of nature tests; $b$ ) the shape and frequency of vibrations of the block 6; c) the shape and frequency of vibrations of the block 7 
a)

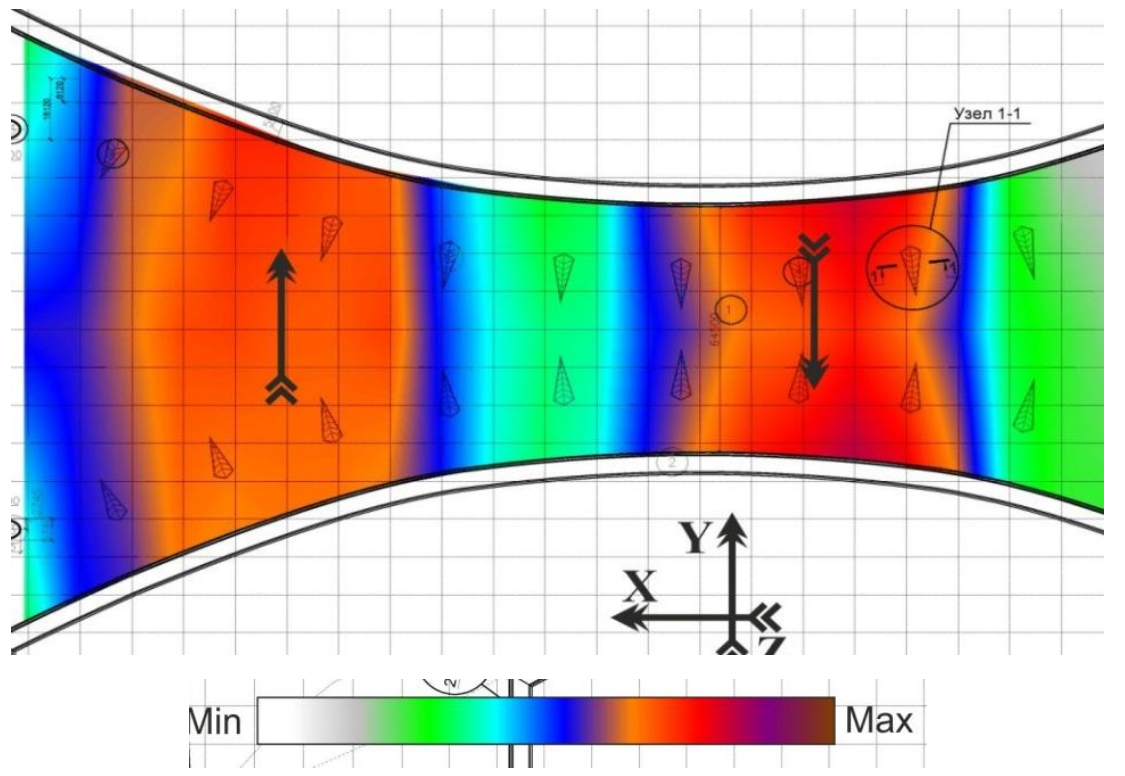

$3.711 \mathrm{~Hz}$

b)

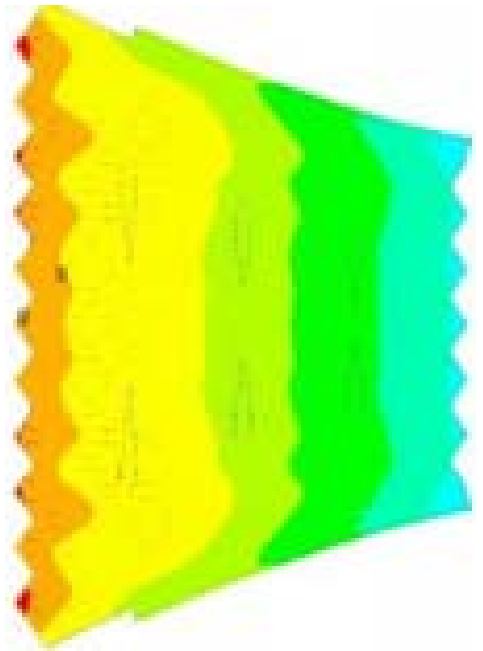

$3.794 \mathrm{~Hz}$

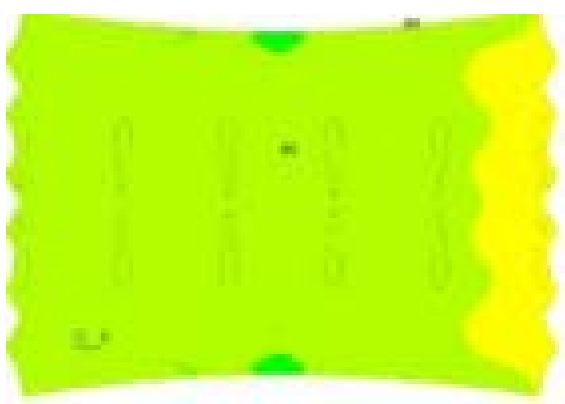

$3.428 \mathrm{~Hz}$

Fig. 8. Comparative analysis of the third transverse waveform: a) the shape (amplitude) and frequency of vibrations of the coating as a result of nature tests; b) the shape and frequency of vibrations of the block 6 ; c) the shape and frequency of vibrations of the block 7

Besides, strength calculations were conducted considering the snow and wind loads. The vertical displacements and angles of rotation relative to the $\mathrm{Y}$-axis of the structural elements of block No. 7 are shown in Figures 9 and 10, respectively. 


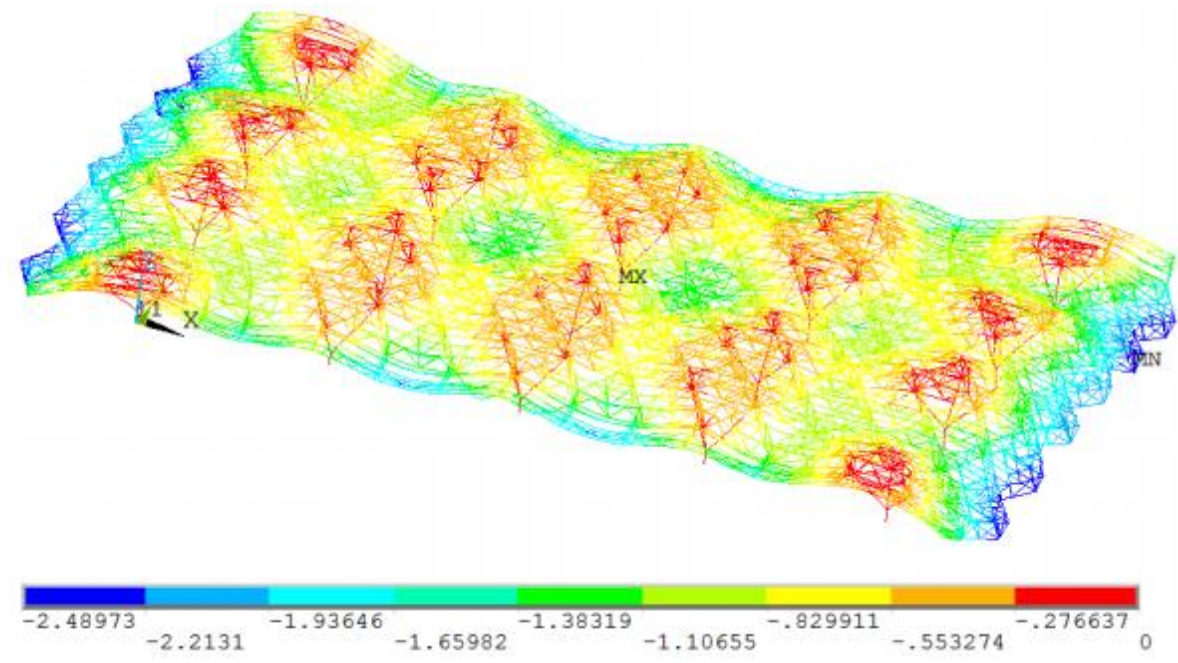

Fig. 9. Vertical displacements of the block 7 structures, $\mathrm{cm}$

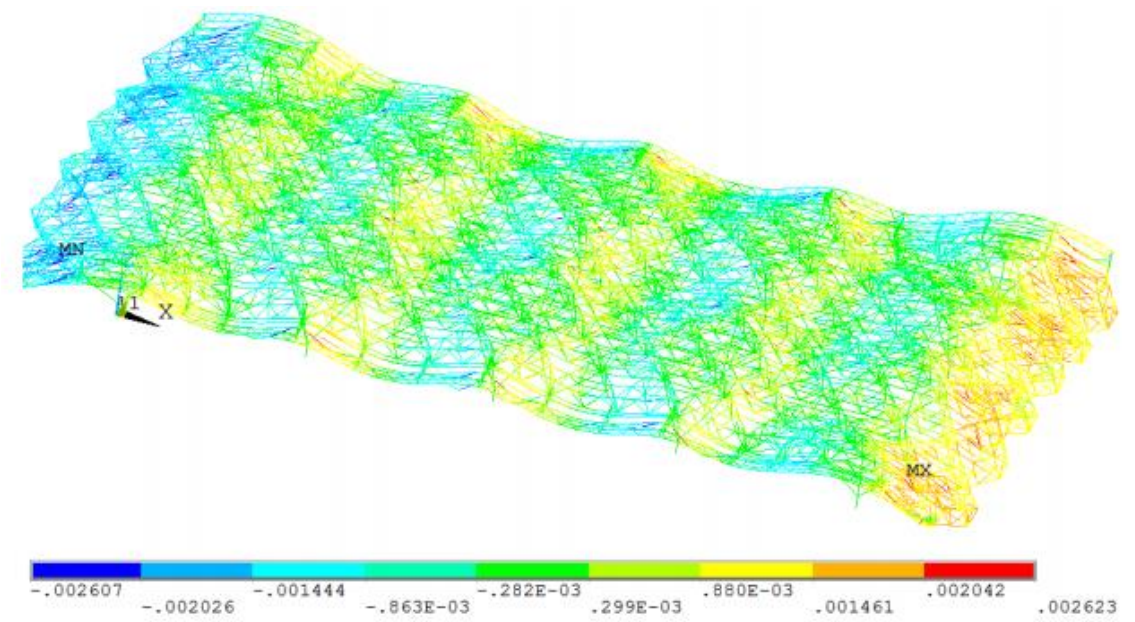

Fig. 10. Rotation angles of the load-bearing structures of block 6 relative to the $Y$-axis, rad

Analysis of displacements and angles of rotation of the elements shows that the monitoring system it is reasonable to use automatic geodetic monitoring stations that control the displacements of significant points with the maximum displacement values, usually at the midspans of the blocks, and inclinometers that control the angles of rotation of the structures of the blocks on the supports. However, it should considering that the obtained maximum displacements for this hazard model $(2.48 \mathrm{~cm})$ are not the limit value of the monitoring system, because the analysis considering the displacements caused by dead load which will already be at moment of the equipment installation.

\section{Conclusions}

1. The development of finite element models for the issues of monitoring requires more detailed analyses, unlike, for example, the verification calculation of load-bearing structures based on the results of the structural inspection, when, in accordance with the current 
regulatory documents, to obtain the parameters of the stress-strain state of a structure, it is sufficient to correctly set the general geometry, cross-section dimensions and material parameters, fixing conditions and operating loads in the numerical model.

2. Additional actions on the model to achieve its adequacy can be:

- determination of the loading conditions of the mass (distributed mass over the model elements, attached mass to the finite element of the model, focused mass in the model node, etc.);

- the use of finite elements for modeling non-load-bearing and enclosing structures with the ability to specify the rigidity characteristics of the elements of these structures (for example, modeling a multilayer shell with layers with different rigidity);

3. To solve the issue of modeling similar structures, it is advisable to automate the process using parameterization tools in programmable software, which will reduce the labor costs and reduce the time of work.

4. The developed models of the coating blocks of the Vnukovo-1 airport complex are suitable for further explores of the influence of various hazard models in order to determine the types and locations of equipment mounting, the limit values of the controlled parameters.

5. The approach considered in this article can be applied to other types of structures of buildings and constructions. This experience will expand the list of additional opportunities for creating adequate computational models.

\section{References}

1. GOST 32019-2012 Technical condition monitoring of the unique buildings and constructions Rules of design and installation of permanent systems (stations) of monitoring.

2. GOST 31937-2011 Buildings and constructions. Rules of inspection and monitoring of the technical condition.

3. A.V. Korgin, M.A. Zaharchenko, M.V. Emel'yanov, V.A. Ermakov, I.V. Rubcov, A.V. Kuhta Analiz normativnoj dokumentacii po monitoringu tekhnicheskogo sostoyaniya zdanij $i$ sooruzhenij, sovershenstvovanie metodov monitoringa na baze centra strukturirovannyh sistem monitoringa VESTNIK MGSU. Pp. 212-221 (2011)..

4. A.V. Korgin, M.A. Zaharchenko, V.A. Ermakov Monitoring tekhnicheskogo sostoyaniya otvetstvennyh sooruzhenij s ispol'zovaniem sovremennyh geodezicheskih metodov izmerenij i chislennogo analiza metodom konechnyh elementov Monitoring. Nauka i bezopasnost'3 Pp. 58-63 (2011).

5. A.V. Korgin, V.A. Ermakov, M.V. Emel'yanov, L.Z. Zeyd Kilani, A.G. Krasochkin, V.A. Romanec Primenenie labview dlya resheniya zadach sbora i obrabotki dannyh izmerenij pri razrabotke sistem monitoringa nesushchih konstrukcij Vestnik MGSU 9. Pp. 134-142 (2013).

6. A.V. Korgin, L.Z. Zeyd Kilani, V.A. Ermakov, A.G. Krasochkin, V.A. Romanec, V.A. Smirnov Programmnaya sostavlyayushchaya avtomatizirovannoj sistemy distancionnogo monitoringa nauchnoe obozrenie 20. Pp. 191-198 (2015).

7. A.V. Korgin, V.A. Ermakov Avtomatizirovannaya aktualizaciya mke-modeli sooruzheniya $v$ hode monitoringa mekhanizaciya stroitel'stva 7 Pp. 16-17 (2011).

8. A.V. Korgin, V.A. Ermakov Avtomatizaciya formirovaniya i korrekcii raschetnyh modelej pri monitoringe tekhnicheskogo sostoyaniya zdanij $i$ sooruzhenij Internetvestnik VolgGASU 3 (2012).

9. S.V. CHirkov, A.A. Tarasenko, P.V. CHepur Konechno-elementnaya model' vertikal'nogo stal'nogo rezervuara s usilivayushchimi elementami pri ego pod"eme gidrodomkratami Fundamental'nye issledovaniya 9 Pp. 1003-1007 (2015). 
10. Koval'chuk O.A., Andreeva P.I. O dinamicheskih harakteristikah zashchitnyh obolochek reaktornogo otdeleniya aes Promyshlennoe i grazhdanskoe stroitel'stvo 10. 2013. Pp. 78-79

11. Andreeva P.I., Zavalishin S.I., SHablinskij G.E. Issledovanie dinamicheskih harakteristik zashchitnyh obolochek aes na fizicheskih $i$ matematicheskih modelyah $v$ naturnyh usloviyah Vestnik MGSU 11. 2013. Pp. 114-122

12. Andreeva P.I., Sergeevcev E.YU., Golovanov A.V., SHCHerbina S.V. Eksperimental'no - raschetnoe issledovanie dinamicheskih harakteristik kupol'noj chasti zashchitnoj obolochki atomnogo reaktora vver-1000 Nauchno - tekhnicheskij vestnik povolzh'ya 6. 2013. Pp. 116-119.

13. Rumyancev A.A., Sergeevcev E.YU. Naturnye issledovaniya dinamicheskih harakteristik chastichno vozvedennogo zdaniya universal'nogo bassejna $v$ g. Anape Vestnik MGSU 5. 2012. Pp. 93-97. 